\title{
Estimating THE LINK BETWEen QuANTITATIVE EASING 3 AND Business InVESTMENT
}

\author{
Joseph Cheng and Julie Fitzpatrick
}

Joseph Cheng (cheng@ithaca.edu) is Associate Professor of Finance and International Business at Ithaca College, 315 Park Center, Ithaca, NY 14850.

Julie Fitzpatrick (Julie.Fitzpatrick@fredonia.edu) is Associate Professor of Finance at SUNY Fredonia, E336C Thompson Hall, Fredonia, NY 14063.

\section{ABSTRACT}

How effective was Quantitative Easing 3 (QE3) in stimulating business investment? Although the link between the financial market and the business sector is often discussed, the precise numerical relationship between financial and business investment is not well understood. In this paper, the "Investment Realization Ratio" is devised for the purpose of elucidating this relationship by quantifying the percentage of funds entering into the financial market that actually translates into business investment. We estimate that the amount of business investment stimulated by QE3 is only a fraction of the amount of bonds purchased by the Fed; this fraction is called the "Investment Realization Ratio." 
Keywords: quantitative easing, large-scale asset purchases, unconventional monetary policy, business investment.

\section{INTRODUCTION}

The financial markets provide most of the funds to business for acquisition of productive assets such as new plants and equipment, generally referred to as business investment. The link between financial investment and business investment is an important topic which is widely discussed. However, the precise quantitative relationship between the funds channeled into the financial market and the amount spent on business investment is not well understood - not that it is intrinsically complex, but because there is a lack of a model which could illustrate this relationship in a straightforward manner. As a result, the relationship between 'Main Street' where production occurs and 'Wall Street' where financial deals are made remains a mystery to many.

Consider the following example. If the Federal Reserve infuses $\$ 100$ million into the financial market by purchasing $\$ 100$ million of Treasury bonds, then the government would need to borrow $\$ 100$ million less from households, leaving $\$ 100$ million more available for business loans. Does this imply that business investment will rise by $\$ 100$ million? This is a basic and important question with implications for monetary policy.

In this paper, we devise the "Investment Realization Ratio" to quantify the degree of responsiveness of business investment to changes in funds flowing into the financial market. The ratio quantifies the relationship between business investment and financial investment by providing a straightforward measure of the amount of financial investment which actually translates into business investment. 


\section{Prior Literature}

The Federal Reserve's conventional monetary policy targets the level of short-term interest rates through the purchase or sale of short-term Treasury securities. In response to the recent financial crisis, the Fed lowered the target Federal Funds rate from 5.25\% to near zero. To stimulate the economy while faced with a "zero lower bound," the Fed then adopted Quantitative Easing (QE) as an aggressive expansion of monetary policy. Also referred to as Large-Scale Asset Purchases (LSAPs), QE involves the Fed's purchase of longer-term securities to lower long-term interest rates and to increase lending, the goal of which is to increase investment and thus employment, thereby stimulating the economy. Since the Fed pays excess reserves to banks in exchange for long-term mortgage-backed securities, one effect of $\mathrm{QE}$ was a significant increase in U.S. bank excess reserves (Investment implications of an 'activist' Federal Reserve, 2013).

QE was initiated in November 2008 during the peak of the financial crisis when the Federal Reserve began purchasing $\$ 600$ billion in mortgage-backed securities. This action was later suspended but resumed in November 2010 with the purchase of $\$ 600$ billion in Treasury securities through the second quarter of 2011 when the U.S. economy was not growing as hoped. Since this was considered the second round, it became known as QE2. In September 2013, the Federal Reserve announced an open-ended purchase of mortgage-backed securities that became known as QE3. Due to improvement in the financial markets and employment data, QE3 was gradually tapered during 2014 and finally ended in October 2014.

According to Bernanke in a 2009 speech, "the idea behind quantitative easing is to provide banks with substantial excess liquidity in the hope that they will choose to use some part of that liquidity to make loans or buy other assets. Such purchases should in principle both raise asset prices and increase the growth of broad measures of money, which may in turn induce households and businesses to buy non-money assets or to spend more on goods and services." The extent to which QE achieved this 
objective, however, is debatable. Unlike the literature on conventional monetary policy, there is relatively little research on the effects of $\mathrm{QE}$ on investment in the United States.

Several empirical studies find that $Q E$ has been associated with increases in both GDP growth and inflation, with estimates of GDP growth increases ranging from $0.1 \%$ to $8.0 \%$ (Baumeister and Benati, 2010; Fuhrer and Olivei, 2011; et al.). However, other research questions the effectiveness of QE. Hall (2013) points to the slow economic recovery to conclude that "both quantitative easing and forward guidance, as implemented by the Fed, are obviously weak instruments." In his commentary to Hall's research, Shin notes that total credit to U.S. non-financial businesses, which rely on bank financing, has been "essentially stagnant." Krishnamurthy and Vissing-Jorgensen (2013) find that QE has had little "portfolio balance" effects on other interest rates and was not macro-stimulus. "A limited benefit did result from mortgage-backed securities purchases due to the announcement effects, but even this small plus may be erased once the still unknown exit costs are included."

While prior research has explored the effects of $\mathrm{QE}$ on various macro variables, the key question that we address is whether the higher financial investment associated with QE increases business investment, and if so, by how much. According to Dobbs et al. (2013), although near-zero interest rates increased U.K. and U.S. corporate profits by $5 \%$ in 2012, "this has not translated into higher investment, possibly as a result of uncertainty about the strength of the economic recovery, as well as tighter lending standards." Net private non-residential investment in the U.S. actually fell by $80 \%$ as a \% of GDP between 2007 and 2009, and U.S. Business Investment is still at its lowest level as a share of GDP since 1947.

A December 2012 Citi Market Outlook study supports this view, showing a downward trend in Capex/Sales ratios for publicly-traded companies worldwide over the past decade, where the Capex/Sales ratio is equal to Capital Expenditure (total investment spending on plant and equipment) as a percent of Sales Revenue. While QE succeeded in 
reducing the interest rates paid by corporate borrowers leading to an increase in issuances, "this burst of issuance does not seem to reflect a confident corporate sector borrowing heavily to fund expansionary capex. Rather, CEOs seem to have used this money to refinance old debts." In fact, the authors argue that "at the margin, current valuations encourage CEOs to distribute through buybacks or dividends. They discourage capex and job creation” (Is Quantitative Easing Working?, 2012).Finally, the 2012 Duke University / CFO Magazine Global Business Outlook Survey provides further evidence that QE may not significantly affect business investment. Six hundred and sixty seven CFOs responded to several questions designed to assess the sensitivity of capital spending to interest rate changes. In response to the question, "By how much would your borrowing costs have to decrease to cause you to initiate, accelerate or increase investment projects in the next year?," only $3.0 \%$ (5.7\%) would initiate, accelerate or increase investment given a 50 (100) basis point reduction in borrowing costs. The survey results suggest that planned capital expenditure is insensitive to interest rate changes and paints a bleak picture of the effectiveness of QE. One CFO offered the following explanation: "Interest rates (are) already at historic lows. It's not high interest rates that are holding us back, but uncertainty about federal policies and loss of financial wealth of our customers."

Since most business investment, such as investment in plant and equipment, is long term in nature, long-term interest rates are more relevant to the business decision-making process. And since $\mathrm{QE}$ focuses on the purchase of long-term bonds, it is expected to have a significant effect on long-term interest rates, which should in turn influence the level of capital expenditure taken on by firms.

Preliminary evidence, however, suggests that only a portion of the financial investment created by $\mathrm{QE}$ translates to business investment. The key contribution of this paper is the development of the "Investment Realization Ratio" to quantify the percent of funds entering into the financial market that actually translates to business investment. 


\section{Market Accounting Equations}

To derive the ratio for measuring the percentage of funds in the financial market which actually filters through to the business investment sector, we first set up two accounting equations, one for the financial market sector, and another for the business investment sector:

$$
\mathrm{FT}=\mathrm{FE}+\mathrm{FG}
$$

where

FT = total demand for financial investment

$\mathrm{FE}=$ external financing obtained by business for investment

$\mathrm{FG}$ = financial instrument issued by government

Since the sum of FE and FG represents the total supply of financial investment, (1) states that the demand of financial investment equals the supply at equilibrium. Equilibrium in the business investment sector is represented by

$\mathrm{IB}=\mathrm{FE}+\mathrm{FI}$

where

$\mathrm{IB}=$ amount of business investment

$\mathrm{FE}=$ same as in (1). Financial instruments issued by business (which represents the amount of business investment which is externally financed).

$\mathrm{FI}=$ the amount of business investment financed internally, such as by retained earnings.

Accounting equations (1) and (2) represent the financial sector and the business investment sector, respectively. FE in (2) represents the amount of external financing obtained by business for investment, which involves securing funds from the financial market sector; thus, FE appears in (1) as well, where (1) represents the equality of demand and supply in the 
financial market sector. Note that the link between the financial sector (1) and the business investment sector (2) is through FE.

Solving for FE in (2), we get

$$
\mathrm{FE}=\mathrm{IB}-\mathrm{FI}
$$

The business investment sector can be integrated into the financial sector by substituting (3) into (1), which becomes the accounting equation that links the financial market sector to the business investment sector:

$$
\mathrm{FT}=\mathrm{IB}-\mathrm{FI}+\mathrm{FG}
$$

Equation (4) can be interpreted as the supply for financial assets and it is the base equation from which the Investment Realization Ratio will be developed.

\section{Deriving the Investment Realization Ratio}

For ease of illustration, we assume that the demand for FT is a linear function of numerous factors, such as the interest rate, disposable income, tax rates, etc.

Thus, FT may be written as:

$\mathrm{FT}=\mathrm{FED}+\mathrm{br}+\sum \mathrm{b}_{\mathrm{i}} \mathrm{x}_{\mathrm{i}}$

where

FED = demand or purchase of government bonds by Federal Reserve

$\mathrm{r}=$ interest rate

$\mathrm{b}=$ the coefficient for $\mathrm{r}$ which quantifies the impact of interest rate change on financial investment (FT)

$\mathrm{x}=$ any other factor which affects household demand for FT

Equation (5) may be interpreted as the demand for financial assets. Note that $b$ in (5) is positive since demand for financial assets should increase as the interest rate increases. Since the interest rate is determined 
by supply and demand of financial assets in the financial market, it is an endogenous variable. Thus, interest rate and its coefficient are expressed as a separate term from the other exogenous factors in the linear demand function of FT which is not immediately affected by Fed policy.

Similarly, the demand for business investment by business is specified to be a linear function of interest rate and other exogenous variable such as tax rates, depreciation rates, etc.

$$
\mathrm{IB}=\mathrm{A}-\mathrm{B} \mathrm{r}+\sum \mathrm{B}_{\mathrm{i}} \mathrm{X}_{\mathrm{i}}
$$

where $X_{i}$ 's represent all other exogenous variables which remain constant with respect to Fed policy in the short-term. B represents the coefficient for $r$ which quantifies the impact of interest rate change on business investment (IB). B is positive, and A is a constant which has no bearing on the derivative since the focus of this paper is on the change or impact. Nevertheless, A can be interpreted as the level of business investment that would be taken when the interest rate is zero.

By substituting the demand for financial investment in (5) and the demand for business investment in (6) into (4), business investment is incorporated into the financial market equilibrium:

$$
\mathrm{FED}+\mathrm{b} r+\sum \mathrm{b}_{\mathrm{i}} \mathrm{x}_{\mathrm{i}}=\mathrm{A}-\mathrm{B} \mathrm{r}+\sum \mathrm{B}_{\mathrm{i}} \mathrm{X}_{\mathrm{i}}-\mathrm{FI}+\mathrm{FG}
$$

where the left-hand side of (7) represents the demand for FT and the right-hand side represents the supply. The demand and supply of financial investment (FT), as represented in (7), determine the market interest rate, which can be solved alone:

$$
r=\left(-F E D-\sum b_{i} x_{i}+A+\sum B_{i} X_{i}-F I+F G\right) /(B+b)
$$

$$
8
$$

For the purpose of illustrating how funds flowing into the financial market are transmitted into the business investment sector, the Fed's purchase of bonds may be used as an example. To see how funds infused by the Fed affect the interest rate, we can differentiate the equilibrium 
interest rate in (8) with respect to FED. Before taking the derivative, it is important to understand what changes and what does not change in this model as FED is varied. The initial infusion of funds by the Fed, such as the purchase of Treasury bonds, increases the demand for financial investment, which would raise security prices and lower interest rates, thus enhancing incentives for business to undertake additional business investment.

It is expected that some exogenous variables in (5) and (6), after the initial round, might also be affected by Fed stimulus. For example, real disposable income might eventually rise as a result of the increase in business investment which augments the capital stock and increases productivity. But this would occur after business investment has changed. And since the purpose of this model is to measure the initial impact of monetary policy on business investment, the assumption that the other variables remain constant in the initial round is reasonable in this context.

As the other exogenous variables remain constant during the initial round, the partial derivative of (8) with respect to FED, which captures the effect of Open Market Operations on interest rate is:

$$
\mathrm{r} / \mathrm{FED}=-1 /(\mathrm{B}+\mathrm{b})
$$

Since B and $\mathrm{b}$ are both positive, the value in (9) is negative, indicating that monetary expansion (through purchase of bonds by the Fed) will lower interest rates, as expected. Ultimately, however, we want to analyze the effect of Open Market Operations on business investment, which can be accomplished by taking the derivative of business investment with respect to FED. And since the effectiveness of Open Market Operations in enhancing incentives for business to invest depends partly on the magnitude of the decline in the interest rate, we can write:

$$
\mathrm{IB} / \mathrm{FED}=\mathrm{IB} / \mathrm{r} \mathrm{r} / \mathrm{FED}
$$

As indicated by the two terms on the right-hand side of (10), two hurdles must be cleared before funds entering into the financial market can be translated into capital expenditure. First, funds infused into the 


\section{The BRC Academy Journal of Business Vol. 5, No. 1}

financial market must be sufficient to raise security prices or lower interest rates. Second, business investment decisions must be responsive to the decline in interest rate.

The first term on the RHS of (10) is the change in IB with respect to $r$, which can be derived by taking the derivative of (6) with respect to $r$ :

$\mathrm{IB} / \mathrm{r}=-\mathrm{B}$

Substituting (9) and (11) into (10) yields:

$\mathrm{IB} / \mathrm{FED}=\mathrm{B} /(\mathrm{B}+\mathrm{b})$

The parameters B and b in (12) are actually coefficients or partial derivatives of the linear functions (5) and (6). These partials can be transformed into elasticity terms, which can be written as:

$$
\begin{aligned}
& \mathrm{E}=\mathrm{IB} / \mathrm{r} r / \mathrm{IB}=-\mathrm{B} \mathrm{r} / \mathrm{IB} \\
& \mathrm{e}=\mathrm{FT} / \mathrm{r} \mathrm{r} / \mathrm{FT}=\mathrm{b} r / \mathrm{FT}
\end{aligned}
$$

Note that E and e are the counterparts of the coefficients B and b in percentage terms; they represent the elasticity of business investment and the elasticity of demand for financial investment with respect to interest rate, respectively. Multiplying $\mathrm{r} / \mathrm{IB}$ by both the numerator and the denominator in (12), and using (13) and (14), we get:

$$
\mathrm{IB} / \mathrm{FED}=\mathrm{E} /(\mathrm{E}-\mathrm{e} \mathrm{FT} / \mathrm{IB})
$$

The derivative in (15) provides a quantitative measure of the effectiveness of Open Market Operations in generating new business investment, which we will call the "Investment Realization Ratio." As we will see, the ratio (15) must be less than 1 . Thus, increasing Fed purchases of bonds, equity investments by individuals, or increasing funds in the financial market by other means, will not raise business investment by the same magnitude. This may be surprising to some students who might expect that the amount of increase in business investment will be the same as the increase in financial market funds. We note, however, that the impact of $\mathrm{QE}$ on real investment might not be immediate even though QE's effect 
on the interest rate is quite rapid. Decision makers in corporations need time to evaluate and discuss the profitability of an investment proposal in light of the lower interest rate before they can make a final decision.

\section{Application}

We use recent data to estimate the Investment Realization Ratio for 2013 and 2014.

We first estimate the Investment Realization Ratio using 2013 third quarter data. In a widely discussed paper, Boskin's estimate of the elasticity of consumption with respect to interest rate is -1.06. Based on this estimated elasticity and the aggregate data on savings and interest rate for 2013, we estimate the elasticity of savings with respect to interest rate (e) is 0.48 (see Appendix).

As indicated in Table 1, new corporate and government securities issued (FT) is $\$ 1,014$ billion, and gross domestic investment (IB) is $\$ 3,352$ billion. If we assume that the elasticity of business investment with respect to interest rate (E) is -1 , then the Investment Realization Ratio (15) based on 2013 data is calculated as:

Investment Realization Ratio $=-1 /(-1-.48(1014 / 3352))=0.87$

Thus, one additional dollar flowing into the financial market generates approximately 87 cents in new business investment. We repeat the calculations using 2014 third quarter data and find similar results. The ratio for 2014 is 0.90 , implying that each additional dollar of financial market funds generates approximately 90 cents in new business investment.

A key input, however, is the assumed elasticity of business investment with respect to interest rate (E). To date, a reliable estimate of this elasticity cannot be found from the current literature. A 2002 study of over 30,000 Italian firms finds the elasticity of capital with respect to cost of capital to be approximately -1 . Lacking a reliable estimate based on U.S. data, we assumed E $=-1$ as a lower bound. However, the Duke 
University / CFO Magazine June 2012 Global Business Outlook Survey suggests that this elasticity might be greater than -1 , and this would decrease the sensitivity of business investment to financial investment.

Table 2 provides estimates of the Investment Realization Ratio for values of $E$ ranging from - 0.1 to -1.0. As expected, the estimate of the Investment Realization Ratio is sensitive to E, especially at higher levels of $\mathrm{E}$.

The last column of Table 2 provides estimates of the increase in business investment due to $\mathrm{QE}$ in 2013. The total amount of $\mathrm{QE}$ in 2013 is $\$ 1,020$ billion ( $\$ 85$ billion per month multiplied by 12 months). The estimated amount of increase in business investment due to QE in 2013 (= \$85 billion x 12 months x Investment Realization Ratio) ranges from $\$ 410$ billion to $\$ 888$ billion.

The Investment Realization Ratio applies not only for analyzing funds infused into the financial market via open market operations, but for analyzing funds infused through other means as well. For example, if banks loan out an additional $\$ 100$ million due to a decrease in the discount rate, or because of a reduction in required reserves, then these amounts would also be considered additional funds entering into the financial market, which would lead to an increase of $\$ 70$ million in aggregate capital expenditures if the Investment Realization Ratio is 0.7 , for example.

One might wonder why business investment does not rise by the amount of the increase in funds contributed by the Fed or by individuals. This can be explained as follows. Under normal elasticity scenarios, increasing bond purchases by $\$ 100$ million will not lower the interest rate enough to cause business to increase business investment by exactly $\$ 100$ million. If the Investment Realization Ratio is 0.7 , for example, then the interest rate will be reduced to a level such that the business investment would only increase by $\$ 70$ million. Now, the next question is what happened to the other $\$ 30$ million? The decline in interest rate would reduce the demand for financial investment in the private sector. At these levels of elasticities, households would decrease demand for 
financial investment by $\$ 30$ million, thus generating a net increase in financial investment of $\$ 70$ million.

One phenomenon to note here is that although the aggregate demand is equal to the sum of individual demands in absolute terms, the incremental demand by an institution or individual cannot be simply equated to the net incremental effect on the aggregate level.

Another interesting and perhaps surprising implication of the derived ratio is that the crowding out effect generated by government borrowing not only reduces funds to business in quantitative terms, but also reduces the effectiveness of Fed policy in a qualitative way. This can be seen by revisiting (15):

$\mathrm{IB} / \mathrm{FED}=\mathrm{E} /(\mathrm{E}-\mathrm{e} \mathrm{FT} / \mathrm{IB})$

As government borrowing increases in the financial market, the size of the financial sector relative to the real investment sector (FT/IB) also increases. This causes the denominator of the Investment Realization Ratio to increase, thus lowering the ratio. In other words, an increase in the size the financial sector relative to the real investment sector decreases IB/FED, which can be viewed as a measure of the effectiveness of monetary policy in stimulating business investment.

\section{Conclusion}

We have developed a ratio, called the "Investment Realization Ratio," that can be used to quantify the relationship between financial investment and business investment. Specifically, this ratio measures the percentage of financial investment that trickles down to real business investment. Thus, the ratio can be used to estimate the impact of the Federal Reserve's purchase of financial assets on real business investment, a key component of monetary policy. Using 2013 and 2014 data, we estimate the amount of business investment stimulated by QE3 under various investment elasticity assumptions. We find that the amount of business investment 
realized is only a fraction of the amount of bonds purchased by the Fed. However, the results are sensitive to the elasticity of business investment with respect to interest rate (E). If business investment is more sensitive to a change in interest rate, then the Investment Realization Ratio increases, indicating a greater impact on real investment.

\section{REFERENCES}

Baumeister, C. and Benati, L. (2012). Unconventional monetary policy and the Great Recession: Estimating the macroeconomic effects of a spread compression at the zero lower bound. Working Paper, Bank of Canada.

Bernanke, B. (2009, Oct. 8). Federal Reserve Board conference on key developments in monetary policy, Washington, D.C. Retrieved from http://www.federalreserve.gov/newsevents/speech/bernanke200910 08a.htm

Boskin, M. (1978). Taxation, saving and the rate of interest. fournal of Political Economy 86(2), 3-28. http://dx.doi.org/10.1086/260692

CFO Survey Results. (2012, June). Duke University Fuqua School of Business and CFO Magazine. Retrieved from http://www.cfosurvey. org/12q4/KeyNumbers_2012_Q3_US.pdf

Dobbs, R., Lund, S., Koller, T. and Shwayder, A. (2013). QE and ultralow interest rates: Distributional effects and risks. Discussion Paper, McKinsey Global Institute. Retrieved from http://www.mckinsey. com/insights/economic_studies/qe_and_ultra_low_interest_rates_ distributional_effects_and_risks

Fuhrer, J. and Giovanni, O. (2011). The Estimated macroeconomic effects of the

Federal Reserve's large-scale Treasury purchase program, Public Policy Brief, Federal Reserve Bank of Boston.

Guiso, L., Kashyap, A., Panetta, F. and Terlizzese, D. (2002). How interest sensitive is investment? Very (when the data are well measured). Working Paper, 
University of Chicago Graduate School of Business.

Hall, R. (2013). The Routes into and out of the zero lower bound. Paper presented at the Economic Policy Symposium, Global Dimensions of Unconventional Monetary Policy, Jackson Hole, WY.

Investment implications of an 'activist' Federal Reserve. (2013). Janney, Montgomery, and Scott. Retrieved from http://www.janney.com/File \%20Library/Unassigned/Janney-Investment-Implications-of-ActivistFED_v3.pdf.

Is Quantitative Easing Working? (2012). Citibank Market Outlook. Retrieved from http://www.citi.com/greece/consumer/pdf/ marketupd_22.pdf

Krishnamurthy, A. and Vissing-Jorgensen, A. (2013). The Ins and outs of LSAPs. Paper presented at the Economic Policy Symposium, Global Dimensions of Unconventional Monetary Policy, Jackson Hole, WY.

Shin, H. (2013). Commentary on The routes into and out of the Zero Lower Bound. Paper presented at the Economic Policy Symposium, Global Dimensions of Unconventional Monetary Policy, Jackson Hole, WY.

\section{Web APPE ndix}

A web appendix for this paper is available at:

http://dx.doi.org/10.15239/j.brcacadjb.2015.04.01.wa01

\section{Citation Information}

Cheng, Joseph. and Julie Fitzpatrick. "Estimating the Link between Quantitative Easing 3 and Business Investment." The BRC Academy Journal of Business 5, no. 1 (2015): 3-17. http://dx.doi.org/10.15239/ j.brcacadjb.2015.04.01.ja01 